\title{
A New Formula for Prediction of Crack Widths in Reinforced and Partially Prestressed Concrete Beams
}

\author{
S. H. Chowdhury and Y. C. Loo \\ School of Engineering, Griffith University, Gold Coast Campus, PMB 50 GCMC, Queensland 9726, Australia
}

\begin{abstract}
A new formula for predicting the average crack widths in reinforced and partially prestressed concrete beams has been developed incorporating four governing parameters. The performance of the proposed formula is checked using the authors' test results which includes crack spacing and crack width measurements from 18 reinforced and 12 partially prestressed concrete beams. Also included in the comparison are published data on 76 beams from other laboratory investigations. The comparative study indicates that the predictions are accurate. The performance of the proposed formula is also compared with three major code formulas, viz those recommended in the ACI Building Code, the British Standard and the Eurocode. It is concluded that better correlation with test data is achieved by the proposed formula.
\end{abstract}

KEY WORDS: Beams, Crack Spacing, Crack Width, Partially Prestressed Concrete, Prestressed Concrete, Reinforced Concrete.

\section{INTRODUCTION}

Cracking analysis constitutes a major step in the serviceability design of concrete structures. Cracks of excessive widths contribute to corrosion of the reinforcement, surface deterioration and consequently damage the structure's long-term well being. Moreover, visible cracks may affect the aesthetics and be a cause for concern to the lay person. Hence, prediction and control of cracking and crack widths is essential for serviceability considerations of reinforced and partially prestressed concrete beams.

Prediction of crack widths has been studied by many researchers (Base et. al., 1966; Broms, 1965; Gergely and Lutz, 1968; Meier and Gergely, 1981; Suri and Dilger, 1986). Despite these earlier efforts, spacing and width of cracks under immediate and long-term loading is still unknown for all conditions and certainly different investigators cannot agree on a single approach for their prediction. The available formulas to evaluate crack widths and those adopted in different design codes are approximate and give a wide scatter of predicted values. Furthermore, there are very few crack width formulas which are applicable to both reinforced and prestressed concrete beams. To the best of the authors' knowledge, there are only two such formulas: one recommended in the CEB-FIP Model Code (CEB, 1978) and the other, by Suzuki and Ohno (1984). Here it shall be noted that the formula of Suzuki and Ohno (1984) was based on the CEB (1978)' s.

This paper presents a simple, yet accurate, formula for predicting the crack widths in both reinforced and partially prestressed concrete flexural members. As part of the research, a series of tests on full-size reinforced and partially prestressed concrete beams was carried out. The proposed average crack width prediction formula is derived statistically incorporating four beam parameters namely, the average crack spacings $\left(l_{\mathrm{cr}}\right)$, the ratio of the average bar diameter to the reinforcement 
ratio $(\Phi / \rho)$, the concrete cover (c) and the average spacing between reinforcing bars (s). In a comparative study, the authors' own test results are used to check the performance of the proposed crack width formula. In addition similar checks are carried out using published data from 26 reinforced concrete beams tested by Clark (1956), 16 reinforced concrete beams tested by Chi and Kirstein (1958), and 34 prestressed concrete beams tested by Nawy (1984). The comparison indicates that the predictions are accurate.

To underscore the improvement in accuracy, the proposed formula is also compared with those recommended in three major international codes namely, the ACI Building Code (ACI, 1995), the British Standard (BS, 1985; BS, 1987) and the Eurocode (EC2, 1991). It should be noted here that the Australian Standard (SAA, 1994) does not recommend any formula for the calculation of crack widths.

\section{EXPERIMENTAL PROGRAM}

A test program was carried out (Chowdhury, 1999) to study the cracking behaviour of full-size concrete beams. In included 11 reinforced and 12 partially prestressed simply-supported box beams, 3 two-equalspan continuous reinforced box beams, and 4 solid reinforced simply-supported beams. The main objectives were to observe under static loadings the beams' cracking characteristics in terms of spacing and width. Based on the test data of 4 reinforced an 4 partially prestressed box beams, randomly selected, and explicit formula is developed for predicting the average crack widths in reinforced and partially prestressed beams.

The box beams tested were of lengths $5.5,6.7,6.8$, 8.0 and $12 \mathrm{~m}$ but all had an overall cross section of 300 mm x $300 \mathrm{~mm}$. Ordinary Portland cement (Type GP) was used and the maximum aggregate size was $10 \mathrm{~mm}$. Mild steel hot rolled deformed bars of (Australian) grade $400 \mathrm{Y}$ (with a minimum yield strength, $\mathrm{f}_{\text {sy }}$, of 400 $\mathrm{MPa}$ ) were used as longitudinal reinforcement and 250R plain bars (with $\mathrm{f}_{\mathrm{sy}}=250 \mathrm{MPa}$ ), for the vertical ties. For the partially prestressed box beams high tensile tendons having a nominal diameter of $5 \mathrm{~mm}$ were used. The solid beams were each $2.5 \mathrm{~m}$ long and $150 \mathrm{~mm} \times$ $250 \mathrm{~mm}$ in cross section.

The main design properties of the 15 reinforced simply-supported test beams are summarised in Table 1. For the 3 two-equal-span continuous reinforced beams similar data are presented in Table 2 and those for the 12 partially prestressed beams are given in Table 3 . Typical cross sections of the test beams are illustrated in Figure 1.

\section{Table 1. Details of reinforced simply-supported test beams}

\begin{tabular}{|c|c|c|c|c|c|c|}
\hline \multirow{2}{*}{$\begin{array}{l}\text { Beam } \\
\text { Number }\end{array}$} & \multirow{2}{*}{$\begin{array}{c}\text { Compressive } \\
\text { strength } \\
\text { of concrete, } \\
\mathrm{f}_{\mathrm{c}}^{\prime}(\mathrm{MPa}) \\
\end{array}$} & \multirow{2}{*}{$\begin{array}{l}\text { Type of } \\
\text { beam }\end{array}$} & \multicolumn{2}{|c|}{$\begin{array}{c}\text { Reinforcement } \\
\text { details }\end{array}$} & \multirow{2}{*}{$\begin{array}{l}\text { Reinforcement } \\
\text { ratio, } \rho\end{array}$} & \multirow{2}{*}{\begin{tabular}{|c} 
Beam \\
length \\
$\mathrm{L}$ \\
$(\mathrm{m})$
\end{tabular}} \\
\hline & & & $\begin{array}{l}\text { number } \\
\text { of bars }\end{array}$ & $\begin{array}{c}\text { bar diameter, } \\
\Phi(\mathrm{m} m)\end{array}$ & & \\
\hline 1 & 25.9 & box beam & 3 & 20 & 0.01154 & 5.5 \\
\hline 2 & 27.1 & box beam & 3 & 20 & 0.01154 & 5.5 \\
\hline 3 & 26.1 & box beam & 3 & 20 & 0.01154 & 5.5 \\
\hline 4 & 30.0 & box beam & 3 & 20 & 0.01154 & 5.5 \\
\hline 5 & 37.7 & box beam & 3 & 20 & 0.01163 & 5.5 \\
\hline 6 & 25.4 & box beam & 6 & 20 & 0.02309 & 5.5 \\
\hline 7 & 32.4 & box beam & 6 & 20 & 0.02326 & 5.5 \\
\hline 8 & 31.0 & box beam & 3 & 20 & 0.01154 & 6.7 \\
\hline 9 & 33.8 & box beam & 6 & 20 & 0.02309 & 6.7 \\
\hline 10 & 28.4 & box beam & 6 & 24 & 0.03348 & 6.7 \\
\hline 11 & 27.6 & box beam & 3 & 20 & 0.01154 & 8.0 \\
\hline 12 & 37.1 & solid beam & 3 & 20 & 0.02990 & 2.5 \\
\hline 13 & 36.6 & solid beam & 3 & 20 & 0.02935 & 2.5 \\
\hline 14 & 34.4 & solid beam & 3 & 20 & 0.02855 & 2.5 \\
\hline 15 & 34.1 & solid beam & 3 & 20 & 0.02855 & 2.5 \\
\hline
\end{tabular}

Table 2. Details of reinforced continuous box beams

\begin{tabular}{|c|c|c|c|c|c|c|c|c|c|c|}
\hline \multirow{2}{*}{ Beam number } & \multicolumn{2}{|c|}{$\begin{array}{l}\text { Positive } \\
\text { reinforcement }\end{array}$} & \multicolumn{2}{|c|}{$\begin{array}{l}\text { Negative } \\
\text { reinforcement }\end{array}$} & \multicolumn{2}{|c|}{ Positive steel } & \multicolumn{2}{|c|}{ Negative steel } & \multirow{2}{*}{$\begin{array}{l}\text { Compressive } \\
\text { Strength of } \\
\text { concrete, } \\
\mathrm{f}_{\mathrm{c}}^{\prime}(\mathrm{MPa})\end{array}$} & \multirow{2}{*}{$\begin{array}{l}\text { Total beam } \\
\text { length }(\mathrm{m})\end{array}$} \\
\hline & $\begin{array}{l}\text { number } \\
\text { of bars }\end{array}$ & $\begin{array}{c}\text { bar } \\
\text { diameter } \\
(\mathrm{mm})\end{array}$ & $\begin{array}{l}\text { number } \\
\text { of bars }\end{array}$ & $\begin{array}{c}\text { bar } \\
\text { diameter } \\
(\mathrm{mm})\end{array}$ & $\begin{array}{c}\text { area } \\
\mathrm{A}_{\mathrm{s}}\left(\mathrm{mm}^{2}\right)\end{array}$ & $\begin{array}{c}\text { ratio } \\
\rho\end{array}$ & $\begin{array}{c}\text { area } \\
\mathrm{A}_{\mathrm{s}}\left(\mathrm{mm}^{2}\right)\end{array}$ & $\begin{array}{c}\text { ratio } \\
\rho\end{array}$ & & \\
\hline 16 & 3 & 20 & $\begin{array}{l}1 \\
2 \\
2\end{array}$ & $\begin{array}{l}24 \\
10 \\
20\end{array}$ & 942 & .01163 & 1238 & .01519 & 34.1 & 12 \\
\hline 17 & 6 & 20 & $\begin{array}{l}2 \\
4\end{array}$ & $\begin{array}{l}24 \\
20\end{array}$ & 1884 & .02361 & 2160 & .02714 & 34.2 & 12 \\
\hline 18 & 4 & 24 & 5 & 24 & 1808 & .02283 & 2260 & .02854 & 30.6 & 12 \\
\hline
\end{tabular}


Table 3. Details of partially prestressed box beams

\begin{tabular}{|c|c|c|c|c|c|c|c|c|}
\hline \multirow[b]{2}{*}{ Beam number } & \multicolumn{2}{|c|}{ Prestressing steel } & \multicolumn{2}{|c|}{ Reinforcing steel } & \multirow[b]{2}{*}{$\begin{array}{l}\text { Reinforcement } \\
\quad \text { ratio, } \rho\end{array}$} & \multirow[b]{2}{*}{$\begin{array}{c}\text { Degree of } \\
\text { Prestressing }\end{array}$} & \multirow{2}{*}{$\begin{array}{l}\text { Compressive } \\
\text { strength of } \\
\text { concrete } \mathrm{f}_{\mathrm{c}}{ }^{\prime} \\
(\mathrm{MPa})\end{array}$} & \multirow[b]{2}{*}{$\begin{array}{c}\text { Beam Length } \\
\text { L (m) }\end{array}$} \\
\hline & $\begin{array}{l}\text { number } \\
\text { of bars }\end{array}$ & $\begin{array}{c}\text { bar } \\
\text { diameter } \\
(\mathrm{mm})\end{array}$ & $\begin{array}{l}\text { number } \\
\text { of bars }\end{array}$ & $\begin{array}{c}\text { bar } \\
\text { diameter } \\
(\mathrm{mm})\end{array}$ & & & & \\
\hline \multirow[t]{2}{*}{19} & \multirow[t]{2}{*}{2} & \multirow[t]{2}{*}{5} & 1 & 12 & \multirow[t]{2}{*}{0.00737} & \multirow[t]{2}{*}{0.25} & \multirow[t]{2}{*}{25.9} & \multirow[t]{2}{*}{5.5} \\
\hline & & & 2 & 16 & & & & \\
\hline 20 & 5 & 5 & 4 & 12 & 0.00730 & 0.50 & 45.8 & 5.5 \\
\hline 21 & 7 & 5 & 2 & 12 & 0.00511 & 0.75 & 46.4 & 5.5 \\
\hline 22 & 10 & 5 & 1 & 12 & 0.00460 & 1.00 & 31.0 & 5.5 \\
\hline \multirow[t]{2}{*}{23} & \multirow[t]{2}{*}{2} & \multirow[t]{2}{*}{5} & 1 & 12 & \multirow[t]{2}{*}{0.00737} & \multirow[t]{2}{*}{0.25} & \multirow[t]{2}{*}{30.7} & \multirow[t]{2}{*}{6.8} \\
\hline & & & 2 & 16 & & & & \\
\hline 24 & 5 & 5 & 4 & 12 & 0.00730 & 0.50 & 32.4 & 6.8 \\
\hline 25 & 7 & 5 & 2 & 12 & 0.00511 & 0.75 & 33.2 & 6.8 \\
\hline 26 & 7 & 5 & 2 & 12 & 0.00511 & 0.75 & 31.3 & 6.8 \\
\hline \multirow[t]{2}{*}{27} & \multirow[t]{2}{*}{2} & \multirow[t]{2}{*}{5} & 1 & 12 & \multirow[t]{2}{*}{0.00737} & \multirow[t]{2}{*}{0.25} & \multirow[t]{2}{*}{28.4} & \multirow[t]{2}{*}{8.0} \\
\hline & & & 2 & 16 & & & & \\
\hline 28 & 5 & 5 & 4 & 12 & 0.00730 & 0.50 & 39.1 & 8.0 \\
\hline 29 & 7 & 5 & 2 & 12 & 0.00511 & 0.75 & 34.4 & 8.0 \\
\hline 30 & 10 & 5 & 1 & 12 & 0.00460 & 1.00 & 27.8 & 8.0 \\
\hline
\end{tabular}

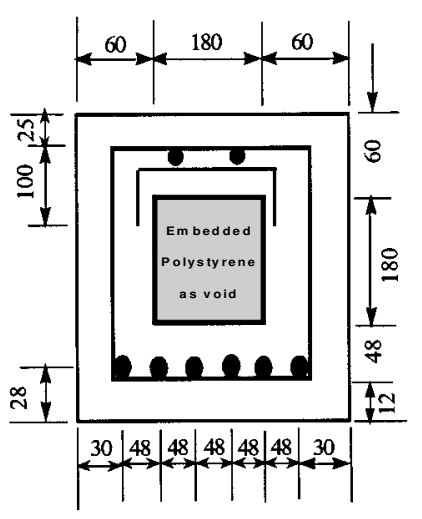

Simply supported RC box beams (beam 10)

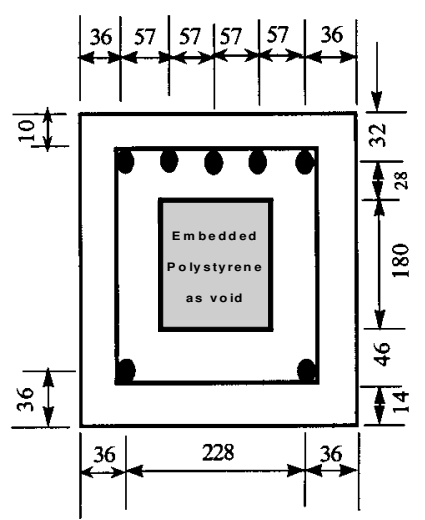

Section over the support

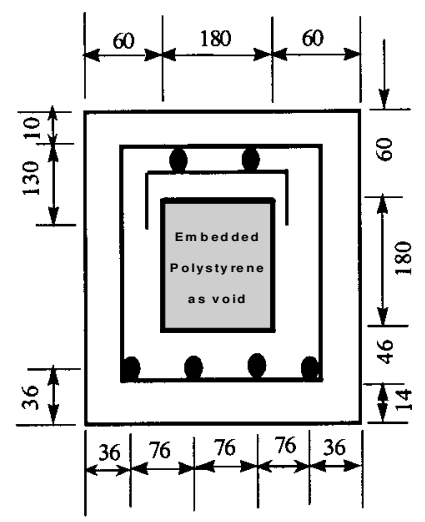

Section at mid-span

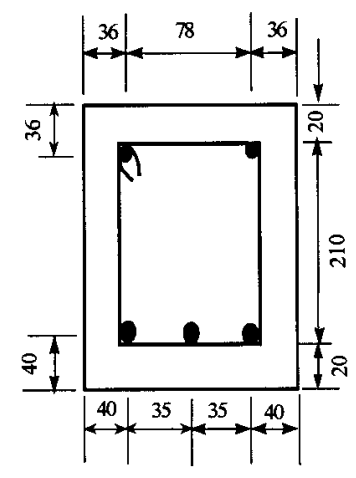

Simply supported RC solid beams (beam 12)

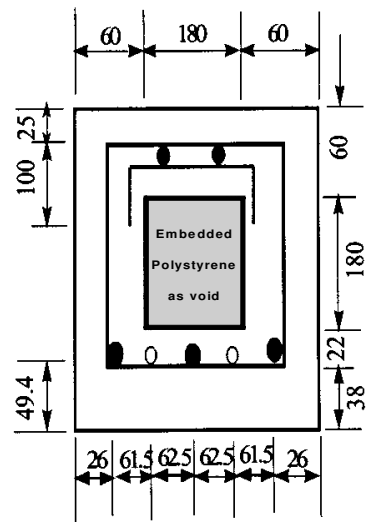

Partially prestressed beams (beams 19, 23 and 27)

Two-equal-span continuous RC box beams (beam 18)

All dimensions are in $\mathrm{mm}$

Figure 1. Typical cross sections for the test beams 
To produce cracking in the beams, static loading was applied. All the beams, except two, were loaded symmetrically at two points at a distance as described in Figure 2. This also applied to each span of the continuous beams. For the simply-supported solid beams 13 and 15, the single point load was applied at the centre of the beam.

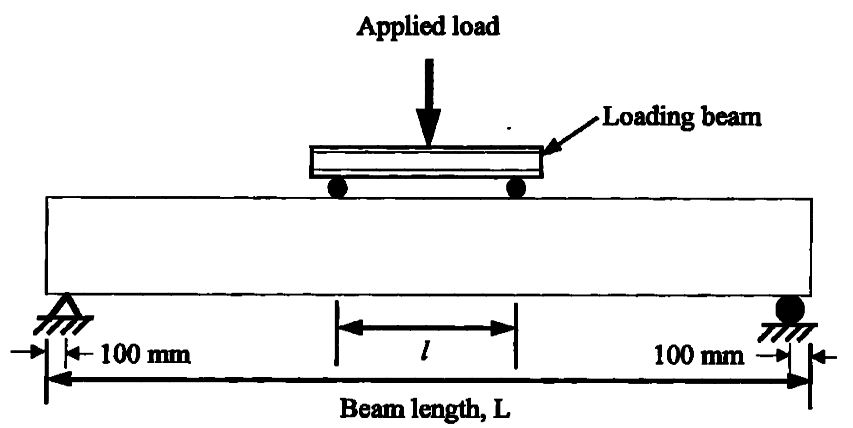

$l=1200 \mathrm{~mm}$ for beams 1 through 4, 6, 8 through 11, and 19 through 30

$l=2000 \mathrm{~mm}$ for beams 5,7 , and each span of beams 16 through 18 $l=800 \mathrm{~mm}$ for beam 12 and $400 \mathrm{~mm}$ for beam 14

Figure 2. Loading arrangements

For each test beam, the instantaneous crack widths at each level of loading were measured using an ELE crack detection microscope (model EL35-2505). The crack spacings were measured at around 60 to $70 \%$ of the ultimate load after they had stabilised.

\section{DERIVATION OF CRACK WIDTH FORMULA}

\subsection{General Remarks}

The opening of a crack is caused by the difference between the elongation of the reinforcing steel and that of the concrete at the same level. Therefore, the crack width may be taken as the elongation of the steel minus the elongation of the concrete between two adjacent cracks. Or,

$$
\mathrm{W}_{\mathrm{cr}}=\varepsilon_{\mathrm{s}} l_{\mathrm{cr}}-\varepsilon_{\mathrm{c}} l_{\mathrm{cr}}
$$

where $\mathrm{w}_{\mathrm{cr}}$ is the average crack width, $l_{\mathrm{cr}}$ is the average crack spacing, $\varepsilon_{\mathrm{s}}$ is the average strain in tensile reinforcement and $\varepsilon_{\mathrm{c}}$ is the average tensile strain in concrete at the same level as the reinforcement.

The elongation of concrete due to the effects of shrinkage and creep are very minor and can be ignored (Nawy, 1996). The concrete strain due to the flexural effect is also minimal. Moreover, by ignoring the term, $\varepsilon_{\mathrm{c}} l_{\mathrm{cr}}$, in Eqn 1, a conservative estimate is produced. The average crack width, thus, can be taken as the elongation of the steel between two cracks, or

$$
\mathrm{w}_{\mathrm{cr}}=\varepsilon_{\mathrm{s}} l_{\mathrm{cr}}
$$

This may be given in terms of the average steel stress, $\mathrm{f}_{\mathrm{s}}$, as

$$
\mathrm{w}_{\mathrm{cr}}=\left(\mathrm{f}_{\mathrm{s}} / \mathrm{E}_{\mathrm{s}}\right) l_{\mathrm{cr}}
$$

where $\mathrm{E}_{\mathrm{s}}$ is the modulus of elasticity for steel.

The phenomenon of crack formation and development is a complex one involving many parameters. According to Nawy (1968), the average crack spacing in reinforced concrete members has obvious relation to the thickness of concrete cover, the diameter of reinforcing bars, the reinforcement ratio and the concrete strength. Many researchers (Clark, 1956; Watstein and Parsons, 1943) have also concluded that the average crack spacing $l_{\text {cr }}$ increases proportionally with $\Phi / \rho$, where $\Phi$ is the average bar diameter and $\rho$ is the reinforcement ratio.

Based on the above findings, three variables were incorporated in the statistical analysis used herein to derive the average crack spacing formula. They are:

(i) the $\Phi / \rho$ ratio;

(ii) $\mathrm{c}$, the concrete cover; and

(iii) $\mathrm{s}$, the average spacing between the reinforcing bars.

Note that since the proposed formula is applicable to normal strength concrete members only and the concrete strengths for such structures vary very little for all practical purposes, the compressive strength of concrete has not been considered in the formulation.

The regression equation takes the form:

$$
l_{\mathrm{cr}}=\mathrm{C}_{1} \mathrm{c}+\mathrm{C}_{2} \mathrm{~s}+\mathrm{C}_{3}(\Phi / \rho)
$$

where $\mathrm{C}_{1}, \mathrm{C}_{2}$ and $\mathrm{C}_{3}$ are the regression coefficients to be determined from the statistical analysis.

\subsection{Average Crack Width Formula}

The relevant data from four reinforced beams (No. 2, 6, 10 and 11) and four partially prestressed beams (No. 21, 23, 24 and 30) were used in the proposed regression analysis, the relevant data for which are presented in Table 4.

The reinforced beams were so selected that they covered all the three beam lengths $(5.5,6.7$ and $8.0 \mathrm{~m})$ and the three different steel ratios (0.01154, 0.02309 and 0.03348). Similarly, the partially prestressed beams covered the three beam lengths $(5.5,6.8$ and $8.0 \mathrm{~m})$ and the four different degrees of prestressing $(0.25,0.50,0.75$ and 1.00$)$. 
Table 4. Parameters used in development of average crack spacing formula

\begin{tabular}{|c|c|c|c|c|c|c|}
\hline Beam number & $\begin{array}{c}\text { Average bar } \\
\text { diameter, } \Phi(\mathrm{mm})\end{array}$ & Steel ratio, $\rho$ & $\begin{array}{l}\text { The ratio } \\
\Phi / \rho(\mathrm{mm})\end{array}$ & $\begin{array}{c}\text { Average spacing } \\
\text { between bars, } \mathrm{s}(\mathrm{mm})\end{array}$ & $\begin{array}{c}\text { Concrete } \\
\text { cover, c }(\mathrm{mm})\end{array}$ & $\begin{array}{c}\text { Average crack } \\
\text { spacing, } l_{\mathrm{cr}}(\mathrm{mm}) \\
\end{array}$ \\
\hline 2 & 20 & 0.01154 & 1733 & 120 & 12 & 131.6 \\
\hline 6 & 20 & 0.02309 & 866 & 48 & 12 & 43.7 \\
\hline 10 & 24 & 0.03348 & 717 & 48 & 12 & 48.7 \\
\hline 11 & 20 & 0.01154 & 1733 & 120 & 12 & 120.0 \\
\hline 21 & 6.6 & 0.00511 & 1292 & 40 & 27 & 126.5 \\
\hline 23 & 10.8 & 0.00737 & 1465 & 62 & 38 & 126.9 \\
\hline 24 & 8.1 & 0.00730 & 1110 & 38.5 & 27 & 118.2 \\
\hline 30 & 5.6 & 0.00460 & 1217 & 40 & 40 & 142.0 \\
\hline
\end{tabular}

The solutions for the regression coefficients (after appropriate rounding) led to the following equation for predicting the average crack spacings (Chowdhury, 1999; Chowdhury and Loo, 1997):

$$
l_{\mathrm{cr}}=0.6(\mathrm{c}-\mathrm{s})+0.1(\Phi / \rho)
$$

where $l_{\mathrm{cr}}, \mathrm{c}, \mathrm{s}$ and $\Phi$ are all in $\mathrm{mm}$.

Substituting Eqn 5 into Eqn 3 yields:

$$
\mathrm{w}_{\mathrm{cr}}=\left(\mathrm{f}_{\mathrm{s}} / \mathrm{E}_{\mathrm{s}}\right)[0.6(\mathrm{c}-\mathrm{s})+0.1(\Phi / \rho)]
$$

which is the new formula proposed for predicting the average crack widths in both reinforced and partially prestressed concrete beams.

Note that the calculated stress in reinforcement at service load, $\mathrm{f}_{\mathrm{s}}$, may be computed as the moment divided by the product of steel area and internal moment arm. Alternatively, $f_{s}$ can be taken as 60 percent of the specified yield strength as recommended by the ACI Building Code (ACI, 1995).

\section{COMPARISON WITH TEST DATA}

The proposed average crack width formula developed herein is compared with the authors' own test data as well as those published by Clark (1956), Chi and Kirstein (1958) and Nawy (1984).

\subsection{Authors' Test Beams}

For each beam, Eqn 6 is applied to different steel stress levels to determine the theoretical values of the average crack widths. These theoretical values are compared with the measured values corresponding to the various steel stresses levels for all the 30 beams. The ratios of the measured and the theoretical values at each load level for each beam are computed. The mean values of these ratios and the corresponding standard deviations for all the beams are tabulated in Table 5 .
Table 5. Relation between measured and computed

\begin{tabular}{|c|c|c|c|c|}
\hline $\begin{array}{l}\text { Beam } \\
\text { number }\end{array}$ & Type of beam & Span/region & $\begin{array}{l}\text { Mean ratio of } \\
\text { measured to calculated } \\
\text { average crack width }\end{array}$ & $\begin{array}{l}\text { Standard } \\
\text { deviation }\end{array}$ \\
\hline 1 & \multirow{12}{*}{ A } & \multirow{15}{*}{ single span } & 1.11 & 0.19 \\
\hline 2 & & & 1.25 & 0.14 \\
\hline 3 & & & 1.05 & 0.08 \\
\hline 4 & & & 1.13 & 0.18 \\
\hline 5 & & & 0.96 & 0.08 \\
\hline 6 & & & 1.16 & 0.16 \\
\hline 7 & & & 1.26 & 0.10 \\
\hline 8 & & & 1.06 & 0.09 \\
\hline 9 & & & 1.03 & 0.10 \\
\hline 10 & & & 1.18 & 0.10 \\
\hline 11 & & & 1.11 & 0.16 \\
\hline 12 & & & 1.11 & 0.22 \\
\hline 13 & \multirow[t]{3}{*}{$\bar{B}$} & & 0.85 & 0.11 \\
\hline 14 & & & 1.00 & 0.20 \\
\hline 15 & & & 1.21 & 0.09 \\
\hline \multirow[t]{3}{*}{16} & \multirow{9}{*}{ C } & positive span 1 & 1.02 & 0.17 \\
\hline & & positive span 2 & 0.99 & 0.19 \\
\hline & & negative span & 1.13 & 0.11 \\
\hline \multirow[t]{3}{*}{17} & & positive span 1 & 1.09 & 0.20 \\
\hline & & positive span 2 & 1.08 & 0.15 \\
\hline & & negative span & 1.19 & 0.15 \\
\hline \multirow[t]{3}{*}{18} & & positive span 1 & 1.17 & 0.09 \\
\hline & & positive span 2 & 1.23 & 0.07 \\
\hline & & negative span & 1.21 & 0.04 \\
\hline 19 & \multirow{12}{*}{$\mathrm{D}$} & \multirow{12}{*}{ single span } & 1.05 & 0.05 \\
\hline 20 & & & 0.84 & 0.08 \\
\hline 21 & & & 0.91 & 0.08 \\
\hline 22 & & & 0.89 & 0.12 \\
\hline 23 & & & 1.17 & 0.04 \\
\hline 24 & & & 0.97 & 0.16 \\
\hline 25 & & & 0.80 & 0.13 \\
\hline 26 & & & 1.08 & 0.11 \\
\hline 27 & & & 1.15 & 0.04 \\
\hline 28 & & & 1.15 & 0.11 \\
\hline 29 & & & 0.87 & 0.21 \\
\hline 30 & & & 1.04 & 0.19 \\
\hline
\end{tabular}
average crack widths for the authors' beams

Note: A: box beams; B: solid beams; C: continuous beams; D: partially prestressed beams. 
An inspection of Table 5 indicates that for the simply-supported reinforced box beams, the mean ratios of the measured to the calculated average crack width values are well within $\pm 30 \%$ i.e. they vary from $-4 \%$ to $26 \%$; and the standard deviation varies from 8 to $19 \%$.

In Table 5, it is further evident that the proposed formula is similarly applicable to solid beams, continuous spans, and partially prestressed beams. The mean ratios vary, respectively, from $-15 \%$ to $21 \%,-1 \%$ to $23 \%$, and $-20 \%$ to $17 \%$; the corresponding standard deviations are 9 to $22 \%, 4$ to $20 \%$, and 4 to $21 \%$.

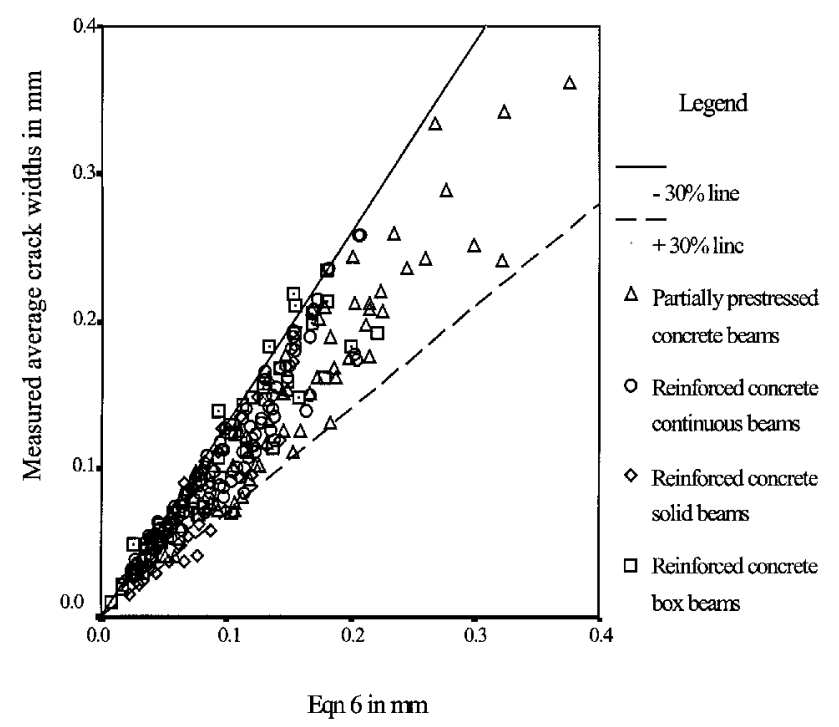

Figure 3. Measured versus calculated crack widths the authors' test beams

Table 6. Relevant data of Clark's, Chi and Kirstein's and Nawy's beams

\begin{tabular}{|c|c|c|c|c|}
\hline Investigator & $\begin{array}{l}\text { Number of beams } \\
\text { used in the present } \\
\text { comparison }\end{array}$ & $\begin{array}{c}\text { Type of } \\
\text { beam }\end{array}$ & $\begin{array}{l}\text { Beam dimensions } \\
\text { in. }(\mathrm{mm}) X \text { in. }(\mathrm{mm})\end{array}$ & $\begin{array}{c}\text { Span } \\
\mathrm{ft}(\mathrm{mm})\end{array}$ \\
\hline \multirow{2}{*}{ Clark (1956) } & 19 & \multirow{2}{*}{$\begin{array}{l}\text { Reinforced } \\
\text { concrete } \\
\text { simply } \\
\text { supported }\end{array}$} & $6(152.4) \times 15(381.0)$ & $9(2743.2)$ \\
\hline & 7 & & $6(152.4) \times 23(584.2)$ & $11(3352.8$ \\
\hline \multirow{4}{*}{$\begin{array}{c}\text { Chi and } \\
\text { Kirstein (1958) }\end{array}$} & 2 & \multirow{4}{*}{$\begin{array}{c}\text { Reinforced } \\
\text { concrete } \\
\text { simply } \\
\text { supported } \\
\end{array}$} & $7.5(190.5) \times 6(152.4)$ & $6(1828.8)$ \\
\hline & 2 & & $11(297.4) \times 6(152.4)$ & $6(1828.8)$ \\
\hline & 8 & & $6(152.4) \times 15(381.0)$ & $9(2743.2)$ \\
\hline & 4 & & $6(152.4) \times 23(584.2)$ & $11(3352.8$ \\
\hline \multirow{3}{*}{ Nawy (1984) } & 18 & \multirow{2}{*}{$\begin{array}{l}\text { Pre-tensioned } \\
\text { prestressed } \\
\text { simply } \\
\text { supported } \\
\end{array}$} & \begin{tabular}{|c|}
$10 \mathrm{in} .(254 \mathrm{~mm})$ deep \\
T-beams \\
\end{tabular} & $9(2743.2)$ \\
\hline & 2 & & $\begin{array}{l}10 \text { in. }(254 \mathrm{~mm}) \text { deep } \\
\text { I-beams }\end{array}$ & $9(2743.2)$ \\
\hline & 14 & $\begin{array}{l}\text { Post-tensioned } \\
\text { prestressed } \\
\text { simply } \\
\text { supported }\end{array}$ & $\begin{array}{c}11 \text { in. }(279.4 \mathrm{~mm}) \\
\text { deep T-beams }\end{array}$ & $7(2133.6)$ \\
\hline
\end{tabular}

The above findings are summarised graphically in Figure 3. A $\pm 30 \%$ band of scatter envelopes the majority of the 258 data points for the beams at different steel stress levels. Note that such a spread is expected and is considered reasonable for flexural cracking problems (Huang, 1975; Nawy, 1984).

\subsection{Other Beams}

To further check the accuracy of the proposed crack width formula, Eqn 6 is compared with the beam test results published by Clark (1956), Chi and Kirstein (1958) and Nawy (1984). For completeness, the relevant beam data are summarised in Table 6 .

Note that the measured crack width values for Chi and Kirstein's beams were at the steel levels whereas the proposed formula gives crack widths at the tension face of the beams. Hence, in order to obtain comparable crack width values at the steel levels, the values calculated using the proposed formula are multiplied by the factor $(d / h)$ where $d$ and $h$ are the effective and total depths of the beam, respectively.

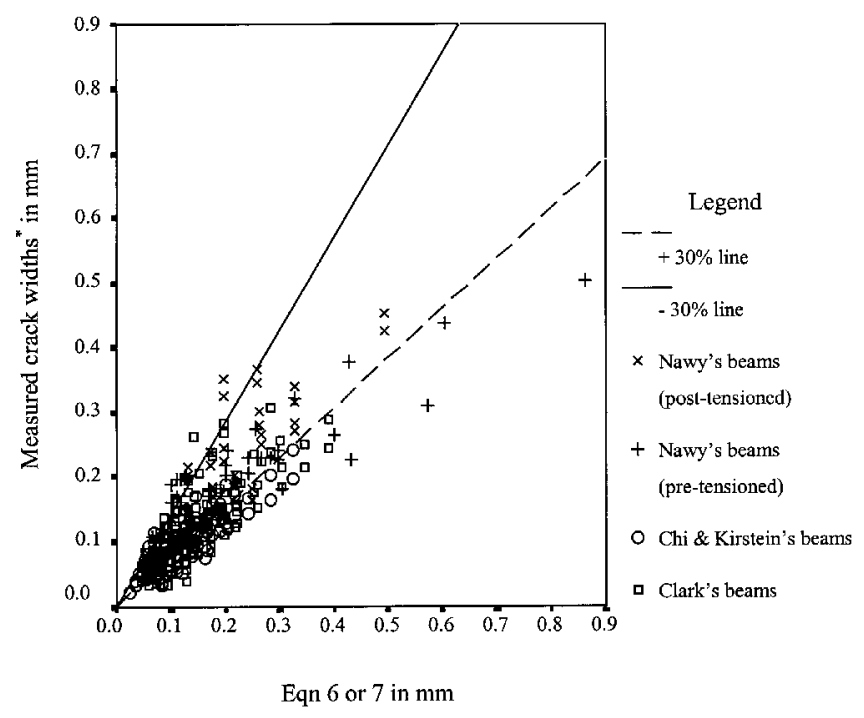

* Maximum crack width values for Nawy's beams and average values for other beams

Figure 4. measured versus calculated crack widths Clark's, Chi and Kirstein's and Nawy's beams

Nawy's measured values were the maximum crack widths which were also measured at the steel level. Hence for the purpose of comparison, the average crack widths obtained using the proposed formula are first multiplied by a factor of 1.5 to get the maximum crack widths. The resulting values are then multiplied by the ratio $(\mathrm{d} / \mathrm{h})$ to get the comparable value at the steel level.

It should be mentioned that the average value for the ratios of maximum to average crack widths lie between 1.3 and 1.7 (CEB, 1978; Chi and Kirstein, 1958; Clark, 
1956; Suzuki and Ohno, 1984; Welch and Janjua, 1971). In the present experimental work (Chowdhury, 1999), the average value for this factor has been found to be 1.46 from the test results of 17 beams. Hence, for the purpose of comparison between different crack width formulas, a value of 1.5 may be adopted for the ratio of maximum to average crack width. In other words, to obtain the maximum crack width, $\mathrm{w}_{\max }$, using the proposed formula, the following formula applies:

$$
\mathrm{w}_{\max }=1.5 \mathrm{w}_{\text {cr }}
$$

where $\mathrm{w}_{\mathrm{cr}}$ is calculated using Eqn 6.

A plot of the measured crack widths against the calculated values for Clark's 26 beams, Chi and Kirstein's 16 beams and Nawy's 34 beams is given in Figure 4 . The data points representing the 4 sets of beams are shown separately in the diagram.

Figure 4 indicates that good correlations exist between the calculated and the measured values for all the beams as a great majority of the 339 data points lie within $\pm 30 \%$ limits and the scattering is acceptably small.

\section{COMPARISON WITH CODE FORMULAS}

To check the relative performance, the proposed average crack width formula is compared with the formulas recommended in the ACI Building Code (ACI, 1995), the British Standard (BS, 1985; Bs, 1987) and the Eurocode (EC2, 1991).

Note that while the ACI code and the British Standard (BS) formulas give the maximum crack widths, the Eurocode formula calculates the average crack widths. The proposed formula that normally calculates the average crack widths can be extended for calculating maximum crack widths using Eqn 7.

Accordingly, the average crack width data is used for comparing the proposed formula with the Eurocode formula. On the other hand for comparison with the ACI code and the BS formulas the maximum crack width data applies. Clark (1956) and Chi and Kirstein (1958) provided both the average and maximum crack width data for their beams. The data for the author's reinforced concrete beams are for average crack widths only.

Since none of the code formulas is recommended for prestressed or partially prestressed concrete beams, the authors' partially prestressed beams and Nawy (1984)' s beams are omitted in this comparison. Note that a multiplying factor of $(\mathrm{d} / \mathrm{h})$ is applied to the calculated maximum crack width values for Chi and Kirstein's beams while using the code formulas. The same factor is also used for the proposed formula to obtain crack widths at the reinforcement level.
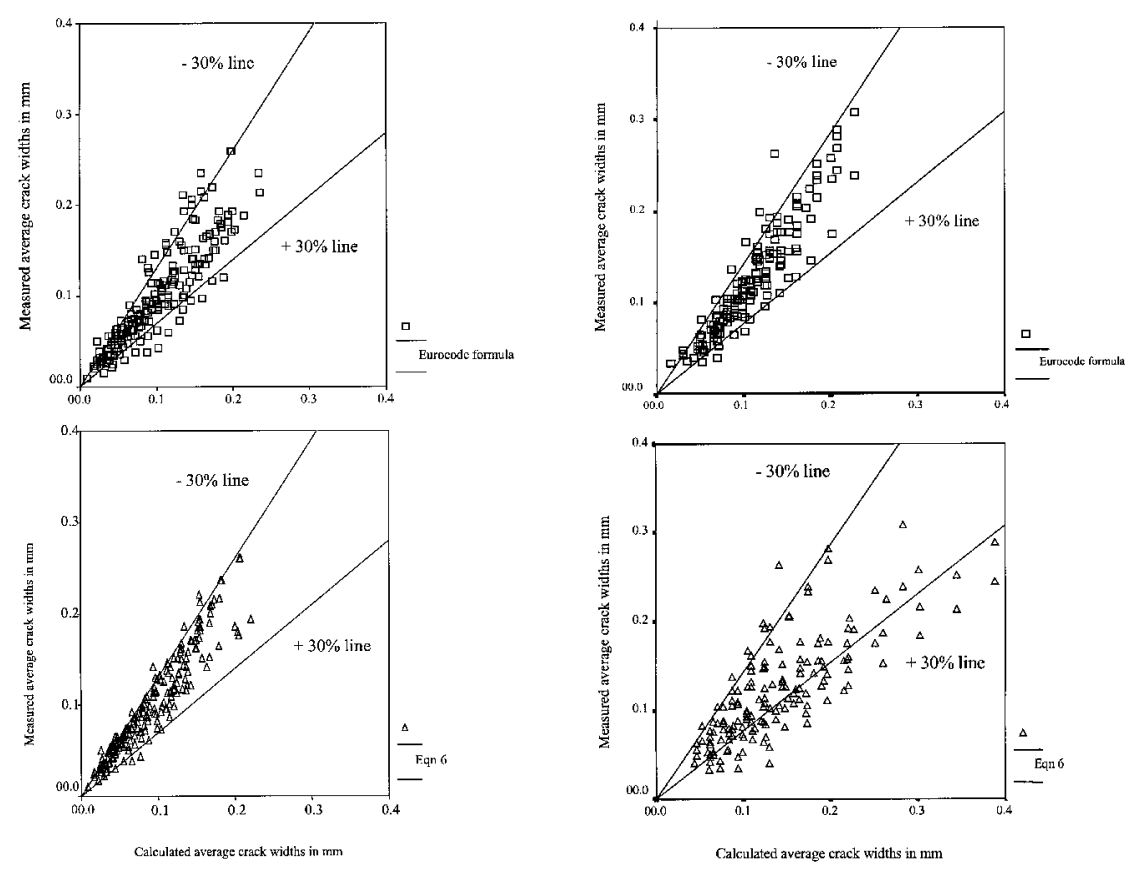

(a) Authors' reinforced beam

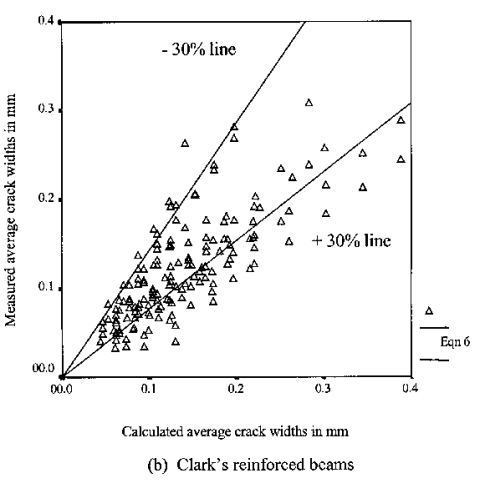

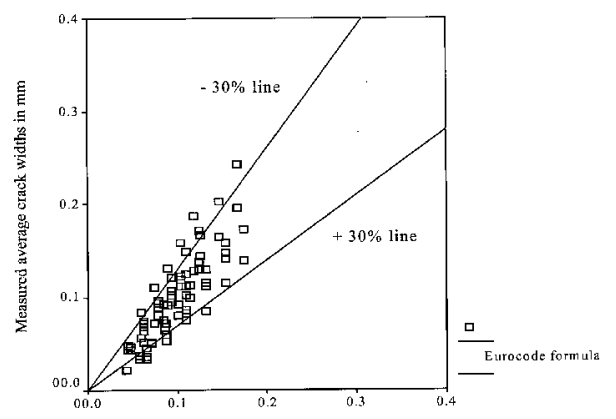

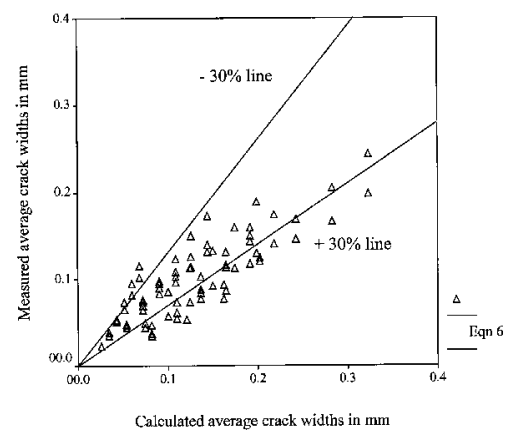

(c) Chi and Kirstein's rcinforced beams

Figure 5. Comparison between the proposed and the Eurocode formulas 
In order to compare the proposed formula with the Eurocode formula, the measured average crack widths are plotted against the values predicted by these formulas in the same correlation plots for the authors' reinforced concrete beams, Clark's beams and Chi and Kirstein's beams. These are presented in Figures 5(a), 5(b) and 5(c) respectively. Similarly, the measured maximum crack widths are plotted against the values predicted by the proposed, the ACI ad the BS formulas in the same correlation plots. These are presented respectively in Figures 6 and 7 for Clark's beams and those of Chi and Kirstein.
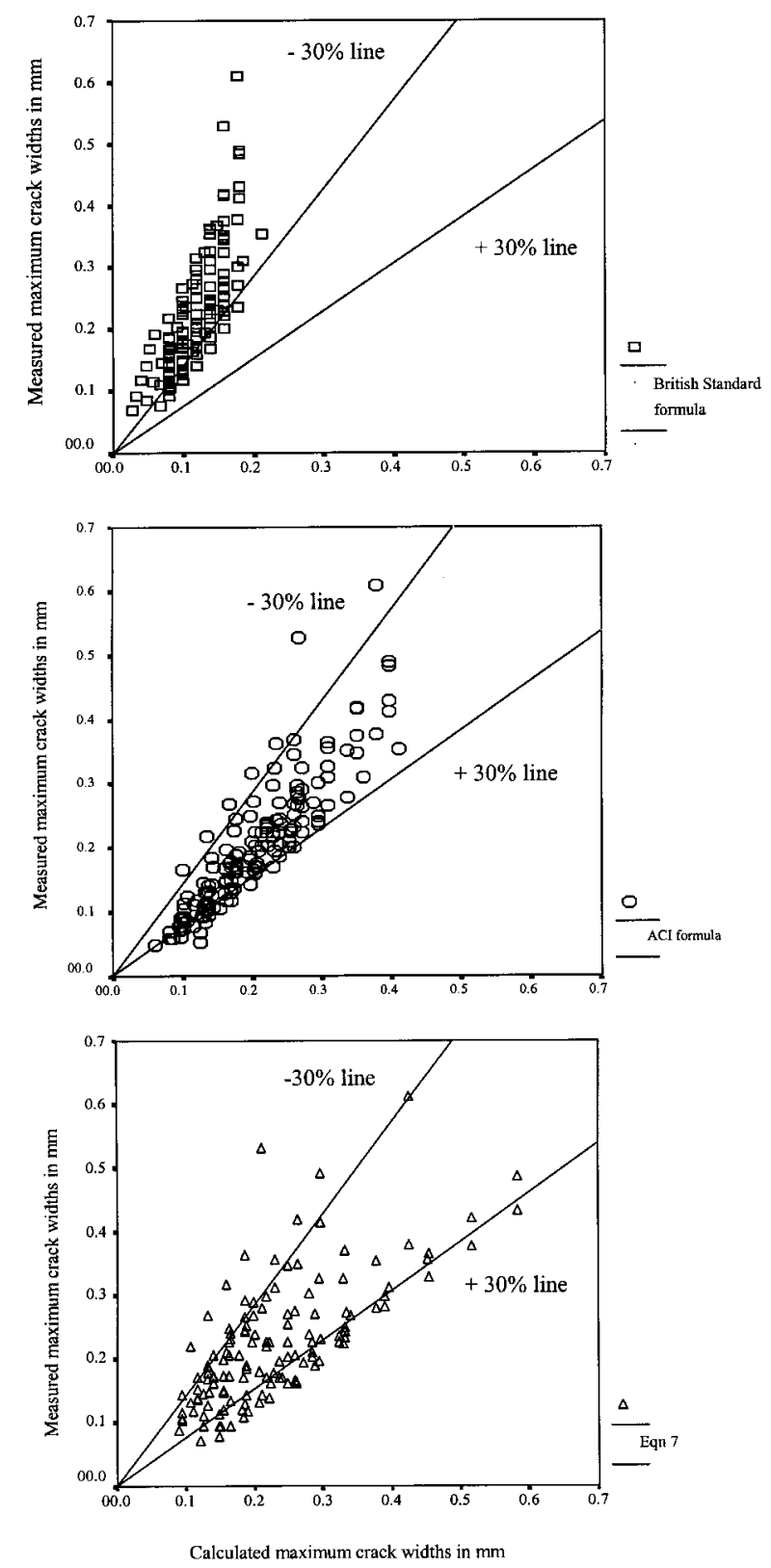

Figure 6. Comparison of measured versus calculated crack widths for Clark's beams
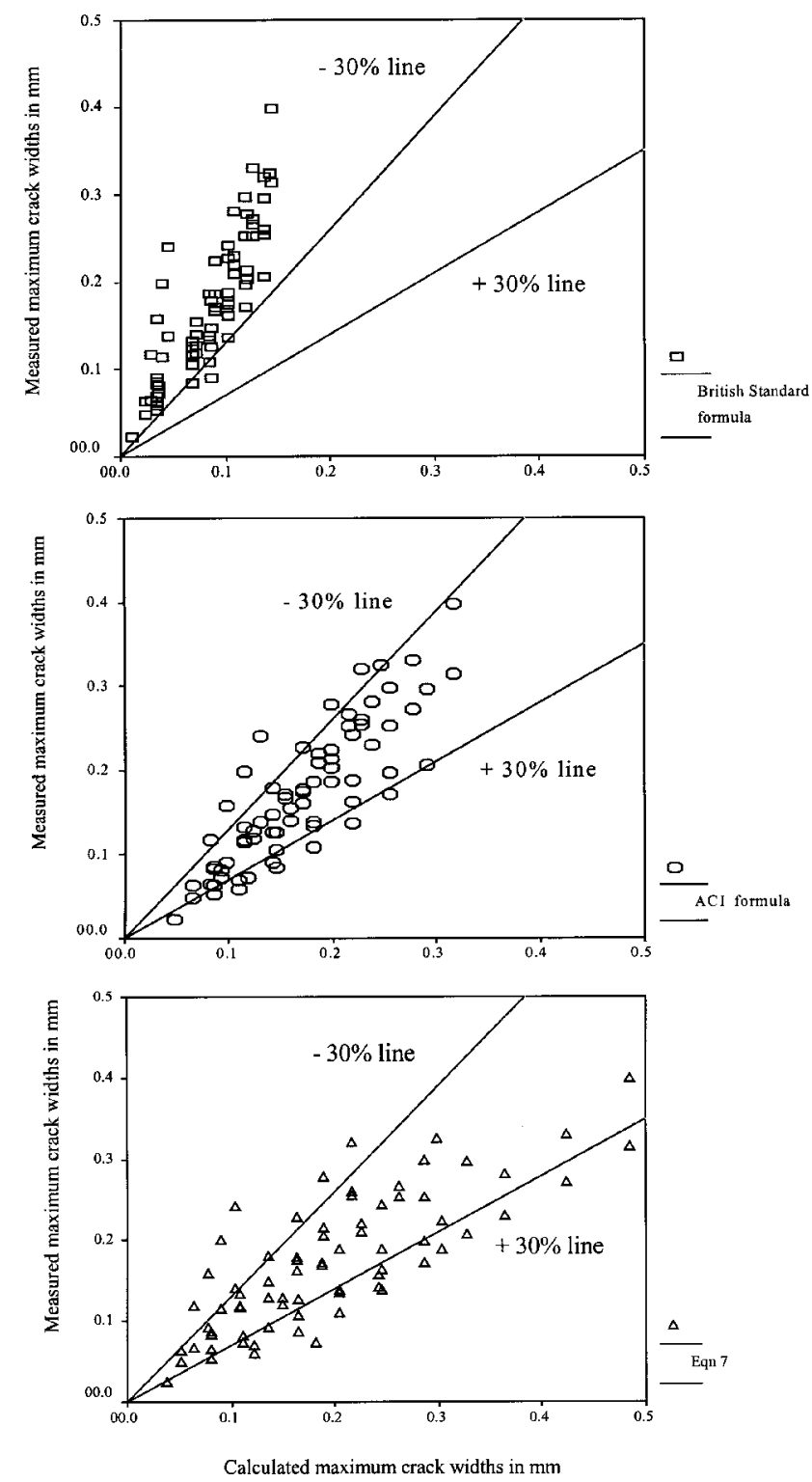

Figure 7. Comparison of measured versus calculated crack widths for Chi and Kirstein's beams

An inspection of Figure 5 reveals that the proposed formula is equally reliable as the Eurocode formula. Also, while the Eurocode formula underestimates the average crack widths for a few beams from each of the three test groups, the proposed formula overestimates the values for a few Clark's and Chi and Kirstein's beams only. As it overestimates the crack width values, the proposed formula is considered conservative.

It is evident from Figures 6 and 7 that while the BS formula grossly underestimates the maximum crack widths for Clark's and Chi and Kirstein's beams, both the proposed and the ACI formulas correlate equally well with this test data. Once again, for a few Chi and Kirstein's beams, the proposed formula overestimates the maximum crack widths and hence, it is on the safe side. 
It is obvious from the above comparisons that the proposed formula is equally reliable as the ACI and the Eurocode formulas. The BS formula, on the other hand, appears to be rather unreliable. It should also be stated that the proposed formula is more versatile because it can predict both the average and the maximum crack widths for both reinforced and prestressed concrete beams. The three design code methods are applicable only to reinforced concrete beams.

\section{CONCLUSIONS}

A new formula is derived statistically for the prediction of average crack widths in both reinforced and partially prestressed concrete beams. The simple explicit formula is suitable for easy manual calculations and can be applied to predict the maximum crack widths using a multiplication factor of 1.5 .

Comparisons with test data from a total of 106 beams indicate that the accuracy of the proposed formula is good. Its performance is as good as those of the ACI and the Eurocode formulas but superior to that of the British Standard recommendation. Compared with all the three code methods, the proposed formula is more versatile as it is applicable to both reinforced and prestressed beams.

\section{ACKNOWLEDGMENT}

The authors are grateful to Mr. Tingkan $\mathrm{Lu}$, a former research student at the University of Wollongong, NSW, Australia for carrying out a portion of the experimental work.

\section{REFERENCES}

American Concrete Institute (ACI) (1995) Building Code Requirements for Structural Concrete (ACI 318-95) and Commentary (ACI 318R-95), Farmington Hills, Michigan.

Base, G.D., Read, J.B., Beeby, A.W. and Taylor, H.P.J. (1966) “An investigation of the crack control characteristics of various types of bar in reinforced concrete beams", Research Report No. 18, Cement and Concrete Association, London, December, Part 1, 44 pp., and Part 2, $31 \mathrm{pp}$.

British Standards Institution (BS) (1985) BS 8110: 1985 Structural Use of Concrete part 2. Code of Practice for Special Circumstances, London.

British Standards Institution (BS) (1987) BS 8007: 1987 Code of Practice for Design of Concrete Structures for Retaining Aqueous Liquids, London.

Broms, B.B. (1965) "Crack width and crack spacing in reinforced concrete members”, ACI Journal, Proceedings, Vol. 62, No. 10, October, pp. 1237-1256.

Chi, M. and Kirstein, A.F. (1958) "Flexural cracks in reinforced concrete beams", ACI Journal, Proceedings Vol. 54, April, pp. 865-878.

Chowdhury, S.H. (1999) Damping Characteristics of Reinforced and Partially Prestressed Concrete Beams, $\mathrm{PhD}$ Thesis, Griffith University, Queensland, Australia.

Chowdhury, S.H. and Loo, Y.C. (1997) "Crack width formula for reinforced and partially prestressed concrete beams", Proceedings, International Conference on Maintenance and Durability of Concrete Structures, P. Dayaratnam and N.V. Ramana Rao, eds., JNT University, Hyderabad, India, March 46, pp. 46-51.

Clark, A.P. (1956) "Cracking in reinforced concrete flexural members", ACI Journal, Proceedings Vol. 52, April, pp. 851-862.

Comité Euro-International du Beton (CEB) (1978) CEB-FIP Model Code for Concrete Structures, English Edition, Cement and Concrete Association, London.

ENV 1992-1-1: Eurocode 2 (EC2) (1991) Design of Concrete Structures, part 1: General Rules and Rules for Buildings, European Prestandard, December, 1991.

Gergely, P. and Lutz, L.A. (1968) "Maximum crack width in reinforced concrete flexural members", Causes, Mechanism, and Control of Cracking in Concrete, SP-20, American Concrete Institute, Detroit, pp. 87-117.

Huang, P-T. (1975) Serviceability Behaviour and Crack Control in Pretensioned Prestressed Concrete I and T Beams, PhD Thesis, Rutgers University, New Jersey.

Meier, S.W. and Gergely, P. (1981) "Flexural crack width in prestressed concrete beams", Proceedings, ASCE, Vol. 107, ST2, February, pp. 429-433.

Nawy, E.G. (1968) "Crack control in reinforced concrete structures", ACI Journal, Proceedings Vol. 65, October, pp. 825-836.

Nawy, E.G. (1984) "Flexural cracking of pre- and post-tensioned flanged beams", Proceedings of the NATO Advanced Research Workshop on 'Partial Prestressing, From Theory to Practice', Paris, France, June 18-22, 1984, M.Z. Cohn, ed., Vol. 2, Martinus Nijhoff Publishers, Dordrecht, 1986, pp. 137-156.

Nawy, E.G. (1996) Reinforced Concrete: A Fundamental Approach, 2nd edn., Prentice-Hall Inc., Englewood Cliffs.

Standards Association of Australia (SAA) (1994) AS 3600-1994: Concrete Structures, Standards Australia, Homebush, NSW, Australia.

Suri, K.M. and Dilger, W.H. (1986) "Crack width of partially prestressed concrete members", ACI Journal, Proceedings, Vol. 83, No. 5, Sept./Oct., pp. 784-797.

Suzuki, K. and Ohno, Y. (1984) "Crack width and crack control of PPC members", Proceedings of the NATO Advanced Research Workshop on 'Partial Prestressing, From Theory to Practice', Paris, France, June 18-22, 1984, M.Z. Cohn, Ed., Vol. 2, Martinus Nijhoff Publishers, Dordrecht, 1986, pp. 157-173.

Watstein, D. and Parsons, D.E. (1943) "Width and spacing of tensile cracks in axially reinforced concrete cylinders", Journal of Research, National Bureau of Standards, Vol. 31, No. RP 1545, July, pp. 1-24.

Welch, G.B. and Janjua, M.A. (1971) Width of Spacing of Tensile Cracks in Reinforced Concrete, UNICIV Report No. R76, University of New South Wales, Kensington. 


\section{NOTATION}

$\mathrm{A}_{\mathrm{st}}$
$\mathrm{b}$
$\mathrm{C}_{1}, \mathrm{C}_{2}$ and $\mathrm{C}_{3}$
$\mathrm{c}$
$\mathrm{d}$
$\mathrm{E}_{\mathrm{s}}$
$\mathrm{f}_{\mathrm{s}}$
$\mathrm{h}$

$=$ area of steel in tension

$=$ width of the beam

$=$ regression coefficients in Eqn 4

$=$ clear concrete cover

$=$ effective depth of the beam

$=$ elastic modulus of elasticity for steel

$=$ tensile steel stress

$=$ height of the beam $l_{\text {cr }} \quad=$ average crack spacing in beam

$\mathrm{s}=$ average spacing between bars

$\mathrm{w}_{\mathrm{cr}} \quad=$ average crack width in beam

$\varepsilon_{\mathrm{c}}$

$=$ average strain in concrete at the level of reinforcement

$=$ average strain in tensile reinforcement

$=$ average bar diameter of tensile bars

$=\mathrm{A}_{\mathrm{st}} / \mathrm{bd}=$ reinforcement ratio
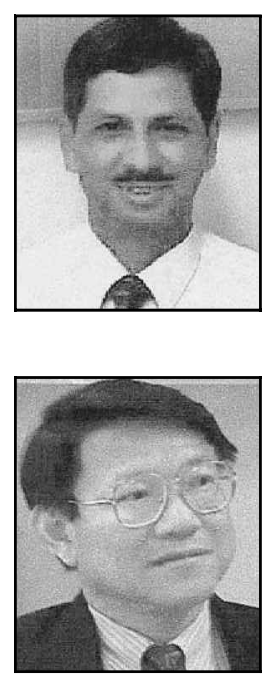

Sanaul H. Chowdhury is a Research Fellow at the School of Engineering at the Griffith University, Queensland, Australia. He graduated from Bangladesh University of Engineering and Technology, Dhaka, Bangladesh and obtained his Master of Technology (MTech) and Doctor of Philosophy (PhD) degrees from the Indian Institute of Technology, Delhi, India and the GriffithUniversity, respectively. Dr. Chowdhury has authored a number of technical papers and his research interests include durability, serviceability, vibration and damping of concrete structures and high strength concrete.

Yew-Chaye Loo is the Professor of Civil Engineering and Head of the School of Engineering at the Griffith University, Queensland, Australia. His current research interests include the strength and serviceability of concrete structures. In addition to numerous research papers, he has published two books, one on bridge engineering and the other on reinforced concrete analysis and design. 